the government is going to extraordinary lengths to suppress news of a plan to build a reconnaissance satellite for recovering information from other people's internal radio transmissions. This coincides with suggestions that the intelligence services have been eavesdropping on the Irish government's private talks about Ulster, but it is unlikely that even the British would deem a satellite necessary for spying on Dublin.

The circumstances are these. A week ago, it emerged that the British Broadcasting Corporation (BBC) had decided, after several weeks of agonizing, not to broadcast a television programme that would have told the tale of the espionage satellite, said to be called Zircon. It emerged that the government had 'advised' the BBC that publication would be unwelcome. The author of the programme, Mr Duncan Campbell, a journalist whose strong suit is itself a kind of intelligence work - the piecing together of interesting tales from published sources, telephone directories, for example - promptly arranged to publish the essence of his story in the political weekly the New Statesman. There followed a series of pantomimic happenings a government attempt to secure an injunction against Campbell (which failed because British judges can restrain only publications), an attempt by the Speaker of the House of Commons to prevent Members of Parliament from seeing the withheld film privately and a police search of the office of the New Statesman and of Campbell's own house. The essence of Campbell's charge is that the British government had been bent on concealing the project not only from the world at large but from the British Parliament. The Prime Minister, Mrs Margaret Thatcher, says that people will be "disgusted" that secrets have been irresponsibly revealed. The leader of the largest opposition party, Mr Neil Kinnock, appears to agree, but accuses the government of incompetence in the management of secrecy.

Several issues arise, of which the chief is the futility of attempting to conceal projects such as that Zircon is said to be. One of Campbell's sources of information appears to have been a series of discrepancies between the British government's published plans for building military communications satellites, many of them proudly announced by the companies awarded the contracts to build them, and the facilities on the ground for handling the signals they would generate. If a mere journalist can infer as much, are not other people's intelligence services likely to know what is afoot? And what purpose can concealment serve in the early stages of such a project when it must be plain that the cat will be out of the bag once the satellite is in place in geosynchronous orbit, where an antenna capable of collecting ground signals could not fail to be a conspicuous radar target? So much is openly recognized in, for example, the United States where, now that the convention that people do not seek to destroy others' satellites has apparently been accepted, the fact of surveillance satellites is openly acknowledged. Secrecy centres instead on what matters - the sensitivity or the resolution of particular devices. It may be inconvenient to be giving other people a few months' advance notice of what is intended (lengthened in this case by the hiatus in US shuttle flights), but what else is to be done in a democracy?

The British government's secrecy about Zircon cannot but reinforce the suspicion that its real anxiety is that otherwise it might be necessary to argue the case for spending $\$ 500$ million, by one estimate the amount needed over five years to put British academic research back on track (see p.377), on this project rather than on others. It is not, after all, that Zircon would have been the first of its kind; US satellites (called Signet) have been in the sky for some years, as have prototypes of the infrared sensors widely canvassed as the work-horses of the Strategic Defense Initiative. Two lessons stand out. First, as the Australian case shows, the most closely guarded secrets eventually become public knowledge. Second, democracies must calculate that the relatively rapid erosion of secrets is the part of the price they pay for their other benefits, among which that of a free press is too lightly scorned in Britain.

\section{Unquiet Chinese science}

Chinese science is being blamed for the unrest among students. Will reform now be halted?

THE news from China is not good. Last week it emerged that Professor Fang Li Zhi had been dismissed as vice-president of the Hefei University of Science and Technology (see Nature 325, $290 ; 1987)$. Now the president of the Chinese Academy of Sciences, Lu Jiaxi, and vice-president, Yan Dongsheng, have been replaced, apparently at the instance of the National People's Congress, the nearest thing in China to a parliamentary assembly. It is as if Dr Frank Press were removed as president of the US National Academy of Sciences by a resolution of Congress, to be replaced by someone chosen by the White House.

The most cheerful reading of events is that the academy is merely being held responsible for having allowed Fang to become an outspoken advocate of democracy in China while playing a key part in the administration of the academy's model university, a remarkable institution that migrated from Beijing to Anhui province to escape the rigours of the Cultural Revolution, and which has ever since enjoyed a measure of independence that would not have been feasible in the capital. In that case, the recent dismissals may be the end of the Chinese government's reaction to last month's student demonstrations in Shanghai, Beijing itself but also in Hefei. The darker reading, and the general fear, is that these sackings are the beginning of a wider repression of free-thinking intellectuals.

For the past 15 years, the government of China has followed an enlightened policy in the encouragement of external links between Chinese researchers and those elsewhere. Both the international community and China itself have benefited enormously from this openness. It is inevitable that some of those who have been personally involved in these exchanges should have come to recognize that there are other and better ways of running research institutions and even governments than those with which China is lumbered.

Paradoxically, some in the Chinese government seem to have been looking for just such a falling of scales from clouded eyes as a by-product of the opening to the West. But both the government of China and the intellectual community are divided in their opinions of these developments. Who can quarrel with the opinion of China's hardliners that there are basic contradictions between the policy of openness towards the West and the maintenance of the bureaucracy of the world's largest and, many Chinese claim, most orthodox marxist state? How, for example, is it possible to reconcile the bourgeois liberal belief that researchers are best employed on what excites their interest with China's bureaucratic method of telling people where to work?

Wherever the upheaval of the past few weeks may lead, it is now inevitable that liberal opinion in China will be stifled, at least temporarily. It is ironical that, in a moving speech at Shanghai at the end of last year, Fang should have been congratulating himself and his colleagues that there was no longer reason to be afraid of speaking out in China. Events have proved him wrong, and the lesson will not be lost on his colleagues. The best hope now is that the damage will be limited. China has already won great benefits from its investment in research since the Cultural Revolution, and from the faltering steps that have been taken to weaken the political constraints on the interests and energies of researchers and to erode the bureaucratic impediments to accomplishment. There is no reason why these processes should not continue while the government of China seeks to come to terms with the underlying contradictions of its policies over the past 15 years. One danger is that it will mistake symptoms for causes, and put even internal reform on hold. The greater danger is that the Party Congress this autumn will take fright at the risks implicit in the contraditions, and turn back the clock to the ending of the Cultural Revolution - or even earlier. 